\section{EFL Teachers' Views on English Assessment in 2013 Curriculum}

\author{
1 Yulnada Sari \\ 2 Efit Eriani \\ 3 Bambang Widi Pratolo
}

123 Universitas Ahmad Dahlan, Indonesia

\begin{abstract}
Teaching English as a foreign language in Indonesia faces several challenges not only from the teachers, students, facilities, teaching and learning process, but also how to assess the students. This present study purposed to investigate the English teachers' views in conducting English assessments accordance in with 2013 curriculum. This study follows a qualitative design of research. The subject of this study is junior high school English teacher in Yogyakarta, Indonesia. The research data were collected through in-depth interview and observation. The results of the study suggested that before teaching, the teachers have prepared the lesson plans which included the rubric of the assessments in 2013 curriculum. English assessments that were used by the teachers were product, skill or knowledge assessment and attitude assessment. In product assessment, there were project and portfolio assessments, while skill or knowledge assessment consisted of writing, speaking, reading, and listening assessments. Thus, most of the teachers agreed with English assessment in 2013 curriculum because attitude assessment is separated from product, skill, and knowledge assessments. This study also revealed that the teachers encountered some problems in conducting the assessments dealing with student's low motivation, lack of vocabulary, large amount of the student in the class, and shortage of teaching duration.
\end{abstract}

\section{Keywords}

English teachers' views

2013 Curriculum

English assessment

Product assessment

Skill assessment

Knowledge assessment

\section{Ethical Lingua}

Vol. 7, No. 1, 2020

ISSN 2355-3448 (Print)

ISSN 2540-9190 (Online)

Corresponding Email

Yulnada Sari

yulnadda@gmail.com

Article's History

Submitted 7 October 2019

Revised 24 October 2019

Accepted 27 October 2019

DOI

10.30605/25409190.121

Copyright $\odot 2020$

The Author(s)

This article is licensed under CC BY-NC-SA 4.0 License 


\section{EFL Teachers' Views on English Assessment in 2013 Curriculum}

Teaching, learning, and assessment are interconnected components which cannot be separated in teaching and learning process (Pratolo, 2015). According to Brown (2003), an assessment is ongoing process that contains a much broader domain. It can be in the form of feedbacks, comments, questions, confirmation, corrections, quizzes, and tests. In other words, assessment is a primary part of the teaching and learning process involving student self-assessment, performance assessment, and portfolio assessment. The teachers can extent and assess how far the purpose of the study, that has been intended, is achieved or applied. Assessment also measures the progress and development of the program. Similarly, the assessment that conducted by the teacher is used to evaluate the progress, process, and the improvement of the learning objectives in the classroom (Maba, 2017). In addition, Mulyasa (2013) asserts that the purpose of the assessment is to ensure the process of learning activities in the class and the performance achieved by the students based on the plan and the objectives of learning. Hence, it can be said that assessment is important in teaching and learning activities because the students can optimally improve their potential which affects the effectiveness of learning. Also, Box, Skoog, \& Dabbs (2015) define that assessment does not only to evaluate the ability of the students in learning but it is also used to understand the weaknesses of the students in learning so that the teacher can adjust their strategies in teaching in order to succeed the learning goals. Therefore, assessment is a process of providing and acquiring needed information of the students in order to create an alternative decision for better teaching and learning activities in the classroom. Moreover, Taras (2005) adds that there are three functions of the assessments. Firstly, assessment is used to investigate the progress and the improvement of the students after experiencing learning activities for a certain period of time. Secondly, it can be used to improve student's way of learning whether they pass or not in the particular educational curricula. Thirdly, assessment is used to identify the success rate of the learning program. Thus, learning is a system that contains of some components which are connected to each other and the components are objectives, methods, learning materials, and strategies in teaching and learning activities. In addition, assessment is a continuous process because it is used to support and monitor the performances of the student in the learning process.

Regarding teaching and learning, curriculum has an essential role in the success of education since without curriculum, it is difficult to achieve the objectives of education. Maba (2017) argues that curriculum is a systematic plan regarding the contents, objectives, and learning materials. It means that curriculum is used to lead the implementation of learning activities in order to reach educational specific goals. Additionally, Ekawati (2016) mentions that a curriculum is interaction planned of the students that contains the material, instructional contents, resources and it is a process for assessing the achievement of the educational objectives or in other word, a curriculum is the complete learning experiences that delivered by a school in which it contains of several courses or syllabus, strategies, and other aspects namely, norms and values which it relates to the ways of the school in organizing it. As well, Nasir (2015) states that the curriculum can change based on the awareness of development that occurs in society such as global challenge, advancement of science and technology. Furthermore, in Indonesia, the curriculum changes in every decade. It caused by many factors namely the changes of society needs, the new insight of teaching and learning process, political issues, development of industry and technology. In other words, the main purpose 
of this change is to improve the quality of education in Indonesia. The education in Indonesia formulates a curriculum based on personal experience through the process of observing, questioning, reasoning, and trying to improve the teacher's creativity and prioritize the attitude, knowledge, and skill aspects (Fadillah, 2014). It means that the change of curriculum requires the improvement of the national education system. Thus, the government in Indonesia has implemented the new curriculum starting from the academic year 2013, namely the 2013 curriculum and it is designed as an attempt to prepare future generation in 2045 .

Related to 2013 curriculum, it is the development of previous curriculum which was called KTSP curriculum. It has a similar basic competency of the curriculum which aims to create competitive and competent students. Hasan (2013) reveals the purposes of the 2013 curriculum. Firstly, 2013 curriculum is to prepare the students to have life skills as individual skill and also makes them to become good citizen in society which are productive, innovative, effective both religious and social attitudes. Besides, they can contribute for the betterment of social, national, and political lives, and humanity. Secondly, it aims in providing the students with the competency to contribute the good of humanity. In addition, there are five considerations in development of the 2013 curriculum which are internal challenge, external challenge, and the perfection of mindset, reinforcement of curriculum management, and deepening and enlargement of the material. According to Nasir (2015), in 2013 curriculum, there is an addition in teaching material that does not exist in the previous curriculum namely individual characters in which the students should be confident, faithful to God, successful in learning, responsible, and giving positive contributions towards society. Therefore, it can be said that the 2013 curriculum is focused on characters building for the students.

According to the 2013 curriculum, assessment processes and the objectives of the assessment become important components in learning activities. In the process of 2013 curriculum assessment especially in high school, the teacher implements authentic assessment in large numbers of the students (Ahmad, 2014). It indicates that the use of authentic assessment is divided into four types of assessment, namely performance assessment, attitude assessment, self-assessment, and portfolio assessment. Moreover, Kunandar (2013) asserts that authentic assessment means the assessment which is based on the actual situation or real life which boost the ability or skill possessed by the students because the term of authenticity means original, real, valid or reliable. In addition, authentic assessment can provide solutions in describing the improvement of the students in learning outcomes, observing, and reasoning, trying, and building networks. Related to the implementation guidelines of the 2013 curriculum, it is inferred that authentic assessment is the most proper technique to use. On the other hand, Maba (2017) argues that the models of assessment that is used by the teacher in the 2013 curriculum are namely, performance assessment, project assessment, written assessment, product assessment, portfolio assessment, self-assessment, and attitude assessment. Furthermore, Newton (2017) defines that from all the models of assessment in 2013 curriculum, attitude assessment or the student's attitude is an important aspect to note down in 2013 curriculum because it could reflect their social attitude in real life. In addition, written assessment is used by the teacher to know the student's potential in writing task, while project assessment is done to give a chance for the students in order to work in a group with their friends. Also, the portfolio assessment is carried out along with performance criteria that are clearly articulated. Parts of the portfolio assessment are checklist, rubrics, rating scales, individual assessment, selfreflection, and teachers' comments. In conclusion, there are various types of the assessments in 2013 curriculum but the main focus of the assessments are to assess student's behavior 
and student's performance in the classroom. Hence, by implemented the 2013 curriculum, the student is expected to be more active than the teacher.

One of the essential parts in the spectrum of 2013 curriculum is English subject in which 2013 curriculum aims to improve students' ability to communicate in English. According to Ashar \& Irmawati (2016), the purpose of English subject as defined in the 2013 curriculum is student can communicate in English with communication skills such as listening, speaking, writing, and reading. In addition, Nur \& Madkur (2014) state that 2013 curriculum is the correction of the previous curriculum. It can be seen from what has happened now in the world of education. Most of the students from high school cannot speak English although in a simple conversation because they encounter the problems. Firstly, the problem is that the students are less to learn about pronunciation, word stressing, and intonation. The coherence among different skills and language components are also not noticed. Then, the four skills in English are not integrated. Secondly, the students are less to learn the activities in English. Thirdly, the students just focus to learn about grammar and vocabulary, but less to learn text. Fourthly, artificial texts are not presented in the real texts. Fifthly, the students are less to practice their language, they only focus in do exercise of reading and writing skills. Sixthly, the activities of teaching and learning process are activities based-text book. Hence, that is why, it makes the students did not have the opportunity to practice English well. Seventhly, the main character of teaching and learning in the class is the teachers. It means, in implementing English assessment, it is inseparable from the role of educators. As professional teachers, they need to update their knowledge especially in English through joining teacher's training, especially under the theme of the 2013 curriculum. Rubin (1975) outlines that the good teacher have to join professional training namely, professional meetings and instructional techniques, master the language proficiency comprises of the four skills in English and cultural comprehension, instructional materials consisted of visual and audio materials, evaluation process which contains assessment of the students and professional testing, and classroom environment such as reduction of the second language anxiety and maintenance of the classroom discipline.

From the explanation above, it can be said that, different experiences of the teacher can influence their understanding in implementing the assessment in the class. Also, they have choices in determining the techniques and approaches to be used in the class and they may use the different technique and approach. As a result, the different techniques of implementing the assessment can make different views of the teacher and it can influence the teacher's behavior on the decision they made in the class. Hence, this research focuses on several junior high school teachers' views on implementing the assessment of English subject in 2013 curriculum and the research questions in this research are as following:

1. What are EFL teachers' views on the implementing of English assessment in 2013 curriculum?

2. What are the difficulties encountered by EFL teachers in conducting English assessment of 2013 curriculum?

\section{Method}

The main objective of this research is to observe junior high school teachers' views on the implementation of English assessment in 2013 in several junior high schools in Yogyakarta, Indonesia. A qualitative approach was used in this research and the data about teachers' views on implementation of English assessment in 2013 curriculum was presented descriptively. 
According to Elliot, Fischer, \& Rennie (1999), the purpose of qualitative research is to demonstrate the understanding of individuals about a certain phenomenon. They further state that "the aims of qualitative research are to apprehend or presents the experiences and actions of people as they encountered, engage, and live through situation" (p. 216). In addition, Jackson, Drummond \& Camara (2007) define that qualitative research is focus on understanding of the human experience views in humanistic approach because one of an important object in qualitative research is human behavior. Ospina (2004) states that there are some reasons to use qualitative study. The first is to analyze a new phenomenon. The second is to add wealthy detail and hint that shows existing knowledge of a phenomenon and generated in qualitatively. The third is to comprehend more about the topic by studying a phenomenon triangulation or concurrently with mixed methods research. The fourth is to advance an original perspective of a phenomenon. The fifth is to understand any social phenomenon from others perspective. The sixth is to know the phenomena in clearly that are impossible to capture in quantitative research approach. The seventh is to understand any phenomenon in complexly.

In addition, a case study was used in this research because this study explores the specific case about junior high school teachers' views on the implementation of English assessment in the 2013 curriculum. According to Yin (1994) a case study is an empirical inquiry that explores the phenomenon within its real-life context, especially when the borders between phenomenon and circumstance are not clearly evident. A case study is used to examine the phenomenon surrounded by the people in real-life context (Yin, 1994). Furthermore, the data collection techniques in this research were in-depth interview and observation. In particularly, this research used semi-structured interview because is measured the participants' opinions, statements, and views even it used to gain the participants' experiences. Cohen, Manion, \& Morison (2011) mention that to get in-depth information, in-depth interview can be used to obtain comprehensive information because it is a discussion between two people including an interviewer and an interviewee. Hence, this research used in-depth interview to get the detail data. In addition, an interview guideline also used in this research as a research instrument. Research instrument is an outline data that was used by the researcher to make discussion become systematic and comprehensive. In the interview guideline, it consists of with open-ended questions which to allow the participant in making choices for responding to the questions. Creswell (2012) defines that an open-ended response enables the participants to make a choice to respond the questions. Besides, the researcher used some tools in conducting the interview. Firstly, cell phone recorder was used by the researcher to record discussion between the participants and interviewer during the interview. Secondly, a notebook was used by the researcher to put the questions that were going to be asked as well as to note the points of the participants' statements. Thus, qualitative interview was used in this research.

Moreover, in order to get in-depth data, the researcher also used observation. According to Creswell (2012), observation is the data collection method in which the researcher investigates the object of the study directly. In this research, the researcher did a direct observation to the class which focusses on the way the teachers implemented the English assessment in 2013 curriculum in the classroom. In addition, Patton (2002) argues that the observer should become a part of the member setting in which they are collecting the data. Hence, the observation checklist also was used by the researcher as the data instrument in this research and it is made in accordance with 2013 curriculum. Therefore, based on the data collection method as mentioned above, the researcher provided some tools such as cell phone recorder and notebook. Cell phone recorder was used to record the discussion and 
conversation between the interviewer and the participants as well as to record teacher's activity in the class. Besides, a notebook was used to note the important point or statement from the participants. As a result, this research has two research instruments that were used by the researcher in gathering the data in which the instruments were interviews protocol and observation checklist. In addition, before the researcher used the instruments in this research, the researcher tested the validity and reliability because validity and reliability should be considered whether the instruments are applicable before they are applied to get the data of the research and it is the important key for effective research. Hence, the validity and reliability of this research were based on expert judgment in which expert judgment is an approach for seeking opinion of the papers on issues requiring policy responses (Otway \& Winterfeldt, 1992).

The participants of this research were chosen using non-random sampling especially purposive sampling technique in order to get various data concerning teachers' views on the implementation assessment in the 2013 curriculum. Purposive sampling is a technique or strategy in which the person or the participant are selected in order to provide the important information that cannot be obtain from the others (Maxwell, 2008). It means, in this research, the researcher has some consideration in choosing the participants and there are some requirements that should be owned by the participants in this research such as they must be an English teacher of junior high school in Yogyakarta and the school where they work should applied 2013 curriculum as the curriculum. Therefore, the five participants in this research were taken no randomly from several schools in Yogyakarta, Indonesia.

In analyzing the data, coding and descriptive analysis were used in this research. In other words, the researcher transcribed the interview recording and made an interview transcript. Creswell (2012) explains transcription is the technique that is used to change audiotape recordings or filled notes to be text data. After that, in order to analyze the data, coding analysis was used to apprehend the data. Coding is giving a name or labeling activity to piece of the text that consists an idea or a part of information (Cohen, Manion, \& Morrison, 2011). Similarly, Creswell (2015) adds that coding is a procedure of analyzing a qualitative text data by put the data separately to see what they yield before they put the data together in a meaningful way. Therefore, coding analysis is divided into four types namely, open coding, analytic coding, axial coding, and selective coding. In addition, the result of structural observation was analyzed in descriptively based on the rating scale of observation.

\section{Results \& Discussion}

The 2013 curriculum is designed to improve the previous curriculum which was KTSP curriculum in Indonesia. The focus of using 2013 curriculum is to improve student's attitude in learning. In Yogyakarta, most of junior high school have implemented the 2013 curriculum especially the English assessment of 2013 curriculum. In addition, there are some assessments that should be done by the teacher in 2013 curriculum, namely written assessment, attitude assessment, project assessment, self-assessment, performance assessment, and portfolio assessment. In order to get deep understanding of 2013 curriculum assessments, the teacher must follow the training of implementation 2013 curriculum. According to the all participants in this research stated that they have joined teachers' training or workshop of the 2013 curriculum, how to implement the curriculum, and the way to assess the students based on 2013 curriculum. According to Rubin (1975), outlines the traits of good language teachers are teachers who have joined professional training, have good language 
proficiency, and the teachers who have provided the evaluation for the students such as giving assessments and professional testing.

\section{Teachers' pros and cons on the implementation of English assessment in 2013 curriculum}

In regard to the implementation of English assessment in 2013 curriculum, the English assessment of 2013 curriculum should be undertaken many processes because there were many aspects that should be evaluated by the teachers. Hence, Nana, Lala, Dimas agreed with the implementation of English assessment in 2013 curriculum as they stated that:

\footnotetext{
"I do agree with K13 because the teachers assess not only the English skills of the students but also their cognitive and motor skills. Curriculum 2013 makes both teacher and student more active and creative. In addition, the teachers must be extra careful in observing and scoring." (Nana).

"Curriculum 2013 is good especially the assessment. In my personal opinion, I agree with curriculum 2013 because K13 makes students to be more active in teaching and learning activities. The example is the students more enthusiasm to do presentation in front of the class in English." (Lala)
"Honestly, one thing that I prefer in curriculum 2013 is attitude assessment that separated to knowledge and skill assessment and for knowledge and skill assessments, I believe we can do all but when we go to attitude assessment in K13, we can control the students to do something good in the class." (Dimas)

As Nana, Lala, and Dimas mentioned about the implementation of English assessment based on 2013 curriculum. It can be said that the aims of the 2013 curriculum is to improve the creativity of the students and it prioritizes the students 'attitude both outside and inside the class. Hence, in English subject, the teachers are not only assessing the four skills in English, but also, they assess the attitude assessment of the students in which it is an important aspect in 2013 curriculum. It is in line with Fadilah (2014), the implementation of assessment based on 2013 curriculum can improve the student's creativity and highlight the attitude, knowledge, and skill aspects.

Meanwhile, Didik mentioned that the assessment in 2013 curriculum especially in English subject is quite complicated because the rubric of English assessment in 2013 curriculum has many variations and they need to develop the rubric based on the situation in the school.

\footnotetext{
"For the assessment, I prefer the previous curriculum because the English assessment of 2013 curriculum is complicated. I mean complicated because of so many model assessments in $\mathrm{K} 13$ and for the rubric itself, it is very time consuming to input the data. It got me confused sometimes." (Didik).
}

Related to 2013 curriculum, one of the important assessments in 2013 curriculum is attitude assessment and Rose defined that conducting attitude assessment is the hardest for her because in conducting attitude assessment, the teacher must be extra carefully since the teachers need to observe their students one by one in the class even outside the class.

"and for attitude assessment, I think, this one is the hardest thing because sometimes, it is too subjective and until now I am still looking for the best formula that makes me not subjective, sometimes, I underestimate my students when they do something bad and 
automatically, I will think that in other activities, they will show bad performance too so I need to learn more to become objective instead of subjective."(Rose).

In conclusion, even though, the assessment accordance with 2013 curriculum especially in English subject is quite complicated but it offers the creativity of the students, using studentcentered learning, assessing both cognitive and motor skills of the students, the teachers can control their students easily. In addition, the most important part of assessment in 2013 curriculum is attitude assessment because in attitude assessment, there is individual character such as responsible, confident, social interaction, faithful to god. Similarly with Nasir (2015), individual characters in 2013 curriculum does not exist in the previous curriculum in which the students should be confident, faithful to God, successful in learning, responsible, and giving positive contributions towards society.

\section{Challenges faced by EFL teachers in conducting English assessment of 2013 curriculum}

With regard to the implementation of English assessment based on 2013 curriculum, the data shows that the models of assessment that used by the teacher to assess the students in the class are namely, attitude assessment, knowledge assessment, written assessment, project assessment, portfolio assessment, self-assessment, and performance assessment. As assert by Maba (2017), in English subject, there are some assessments should be done by the teachers such as performance assessment, project assessment, written assessment, product assessment, portfolio assessment, self-assessment, and attitude assessment. Furthermore, the assessment applied in 2013 curriculum is authentic assessment because it explores the student's creativity and by using authentic assessment the teachers believes that it can provide the solutions in order to help students achieve the learning goals. Authentic assessment can provide the solutions in describing the improvement of the students in learning outcomes and it can help the students to build the motivation of the students (Kunandar, 2013). Similarly, Kunandar (2013) suggests that authentic assessment is the most proper techniques to use in conducting English assessment of 2013 curriculum. They further mention that authentic assessment refers to the multiple forms of the assessment that reveals student's learning, the achievement of the student, motivation of the students, and students' attitudes toward appropriate activities.

However, in conducting the assessment accordance with 2013 curriculum, the teachers encountered some problems dealing with student's motivation, lack of vocabulary, large amount of the student in the class, lack of teaching material, and shortage of teaching duration. It refers to case study which is it used to reveals specific problem faced by the teachers in conducting English assessment in 2013 curriculum. Yin (1994) asserts that case study is used to investigate the specific case or phenomenon surrounded by people. As a result, Nana mentioned that the challenges faced by Nana dealing with student's motivation, large amount of the students and the shortage of teaching duration. It means, when she conducted the assessment in the class, she needs extra time to observe their students one by one to make a better evaluation. Besides, student's motivation also became her obstacles in conducting the assessment because not all the students interested in English.

\footnotetext{
"The students are not interested to the English assessment, so it became one of my problem in conducting the assessment. Besides, in my opinion, it is hard to give the students two assessments together in the class because of the duration of teaching and the activity of the assessment is different too." (Nana).
} 
Related to shortage time of teaching, this problem also mention by Maba (2017), shortage of time and large amount of the students in the class are the problems for the teacher because they need to assess the student one by one according to 2013 curriculum. Similarly, these problems also define by Didik, but he added another problem as the student has limited vocabulary. Didik mentioned that grammatical errors and the error translation in English becomes the problem usually it found in writing and speaking assessments.

\footnotetext{
"One of the problems in my school is lack of student's motivation in learning English and also lack of vocabulary. It still a lot of grammatical error and incorrect translation so it takes a long time when I assessed my students because the more the students we have, the more times we need." (Didik).
}

Moreover, based on the interview result, it can be concluded that the models of assessments that used by the teacher in English subject accordance with 2013 curriculum are product and skill assessments including project assessment, portfolio assessment, and written assessment, while skills assessments including self-assessment, performance assessment, written assessment, speaking assessment, reading assessment, and listening assessment. Besides, after the teacher conducted the assessment, they will make the percentages from the result of assessment and input the data in the 2013 curriculum application. Additionally, related to English subject, it cannot be separated from the four skills in English such as speaking, reading, writing, and listening skills. In order to conduct the four skills in English. The teachers mentioned that one of problem that they encountered is lack of teaching material as Rose stated that:

\footnotetext{
"I feel hard to assess the student's listening skill because of limited teaching material or the facilities of the school so when listening assessment, I do not use the audio, I do it orally." (Rose).
}

In this case, Rose expected to be able to assess the students' four skills in English but lack of teaching material in English becomes one of the problems in conducting the assessment. the teacher felt difficult in assessing the four skills in English such as listening, speaking, writing, and reading because the problem in implementing English assessment of 2013 curriculum is limited supporting material such as textbook (Ashar \& Irmawati, 2016; Ahmad, 2014).

In the observation, the researcher observed the ongoing teaching and learning activity carefully, the researcher focused on the English assessment of 2013 curriculum that was applied by the teacher in the class. Before teaching, the teacher made the lesson plans and those were supplemented by an assessment rubric. The assessments that were applied by the teachers are such as attitude assessment, portfolio assessment, written assessment, project assessment, and self-assessment, performance assessment, reading assessment, and speaking assessment. English assessment was conducted in accordance with 2013 curriculum with the lesson plan. Teaching and learning in the class were carried out based on the steps in the lesson plan. Moreover, the teachers applied authentic learning and the teachers used lecture, question and answer, and discussion learning models. Besides, in every activity, the teachers also observed the students' attitude because the teachers conducted attitude assessment in every activity in the class. In conducting attitude assessment, the teacher carefully observed the behavior, confidence, and responsibility of the students in the class. 
Related to the four skills in English, the teacher conducted speaking and writing assessment together. The instrument that is used in assessing speaking and writing was dialogue text. It means that in writing, the teachers asked the students to write a dialogue and then they present the dialogue in front of the class with their groups. The aspects that were assessed by the teacher are the content, vocabulary, pronunciation, articulation, and grammar. Furthermore, in speaking and writing activities, it is also included self-assessment and performance assessment because the teacher assessed the students' performance with their group when they perform the dialogue in front of the class and for self-assessment, the teacher assessed the student's confidence individually. In addition, in order to conduct project assessment, the teacher also asked the students to make greeting card in which the students make them by using drawing book and they had to make it interesting. Thus, the teacher provided the score criteria for the students in every assessment. The score consists of scores of 1 to 4 , where the score 1 means excellent, 2 score means good, score 3 means sufficient, and score 4 refers to need guidance. Besides, the teachers also provided the remedial test for the students who get 4 .

\section{Conclusion}

In this research, the participants have diverse views toward the implementation of English assessments based on 2013 curriculum but most of the teachers in this research agree with 2013 curriculum since they argued that English teaching and learning according to 2013 curriculum is good because the 2013 curriculum is a value curriculum which is occupied by character building but the English assessment in the 2013 curriculum was quite complicated. In English assessment of the 2013 curriculum, there are so many aspects that should be evaluated by the teachers. In addition, the models of assessment in the 2013 curriculum especially in English subject are namely self-assessment, performance-assessment, speaking assessment, writing assessment, listening assessment, reading assessment, and product assessment which is in product assessment consists of project and portfolio assessment. As well, attitude assessment that is separated from knowledge and skill assessments because the 2013 curriculum focuses on the development of student's attitude such as being good, faithful to God, confident, successful in the learning, becoming a responsible citizen, and giving positive contributions towards society. Thus, it can be said that the most important part in English assessment of the 2013 curriculum is attitude assessment. It means that attitude assessment is included in all of assessments in the 2013 curriculum because in every activity, the teacher evaluates the student's attitude in the class.

Based on the results, assessment of attitude competencies was done by the teachers during the observation of the students in the class, giving the students self-assessment, and asking the students to do peer assessment. In order to assess the students' knowledge, the teachers carried out the skill assessments which are speaking assessment, writing assessment, reading assessment, and listening assessment. Additionally, speaking and writing assessments were done together by the teachers in which they asked the students to write the dialogue based on the proper vocabulary, content, and grammar aspects, after that they performed the dialogue in front of the class and the teachers assessed their speaking and reading skills.

Moreover, in the English assessment of 2013 curriculum, the teachers used authentic assessment in which it is based on the real-life context and in teaching and learning activities in the class, the teacher used collaborating teaching method such as project-based learning or task-based learning. Besides, concerning carrying out the English assessments in the 2013 
curriculum, the teachers also faced some problems dealing with the rubric of the assessment itself, students' low motivation, lack of vocabularies, lack of teaching material, big number of the students in a class and time allocation. After the teacher conducted the assessments in the class, they must input the report in the applications rubric of 2013 curriculum assessments. The report was in descriptive report and it took a lot of time to input the data. In addition, the problems also come from the students, namely student's lack of vocabulary and motivation in learning English so it made the teachers even harder to conduct the assessments in the class. Additionally, big number of the students in the class becomes a problem because the need to assess the students one by one in which the time is limited. Thus, the solution that are provided in overcoming the problems are the teachers should be discipline in inputting the rubric of the assessments to 2013 curriculum application and the teachers need share and discuss the problems in conducting the assessments with peers.

\section{Acknowledgement}

The researcher would like to thank all of my participants in this research and also, the special gratitude goes to the institution, Universitas Ahmad Dahlan that have been facilitated me in completing the research.

\section{References}

Ahmad, D. (2014). Understanding the 2013 curriculum of English teaching through the teachers' and policymakers' perspectives. International Journal of Enhanced Research in Educational Development (IJERED), 2(4), 6-15.

Ashar, A. \& Irmawati, I. (2016). The implementation of the 2013 curriculum of English at SMKN 1 Bantaeng: an evaluative study. ELT Worldwide, 3(2), 156-169.

Box, C., Skoog, G., \& Dabbs, J. M. (2015). A case study of teacher personal practice assessment theories and compxities of implementing informative assessment. American Educational Research Journal, 52(5), 956-983.

Brown, H. (2003). Language assessment principles and classroom practices. California: Longman University Press.

Cohen, L., Manion, L., \& Morrison, K. (2011). Research methods in education. London: Routledge.

Creswell, J. (2015). 30 essential skills for the qualitative researcher. Los Angeles, CA: SAGE.

Creswell, J. W. (2012). Educational research planning, conducting, and evaluating quantitative and qualitative research (4th ed,). Boston: MA Pearson.

Ekawati, Y. N. (2016). The implementation of curriculum 2013: a case study of English teacher's experience at SMA lab school in Indonesia. ELLD Journal, 7(1), 84-90.

Elliot, R., Fischer, C. T., \& Rennie, D. L. (1999). Evolving guidelines for publication of qualitative research studies in psychology and related fields. British Journal of Clinical Psychology, 38(3), 215-229.

Fadillah. (2014). Implementasi kurikulum 2013 dalam pembelajaran SD/Mi, SMP/MTS, dan SMA/MA. Yogyakarta: Ar-Ruzz Media.

Hasan, S. H. (2013). History education in curriculum 2013: a new approach to teaching history. International Journal of History Education, 14(2), 163-178.

Jackson, I. L., Drummond, D. K., \& Camara, S. (2007). What is qualitative research? Qualitative Research Reports in Communication, 8(1), 21-28.

Kunandar. (2013). Penilaian authentik (penilaian hasil belajar peserta didik berdasarkan kurikulum 2013). Jakarta: PT. Raja Grafindo Persada. 
Maba, W. (2017). An analysis of assessment models employed by the Indonesian elementary school teachers. International Journal of Social Sciences and Humanities, 1(1), 39-45.

Maxwell, J. A. (2008). Designing a qualitative study. The SAGE handbook of applied social research methods, 2, 214-253.

Mulyasa. (2013). Curriculum development and implementation 2013. Bandung: PT. Remaja Rosdakarya.

Nasir, Z. I. (2015). Teaching English based on 2013 curriculum at junior high school in Gowa. IJET, 1(2), 246-255.

Newton, P. E. (2017). Clarifying the purposes of educational assessment. Assessment on Education: Principle Policy \& Practice, 14(2), 149-170.

Nur, M. R., \& Madkur, A. (2014). Teacher's voices on the 2013 curriculum for English instructional activities. IJEE, 1(2), 199-133.

Ospina, S. (2004). Qualitative research. London: SAGE Publications.

Otway, H., \& Winterfeldt, D. v. (1992). Expert judgment in risk analysis and management: process, context, and pitfalls. Risk Analysis, 12(1), 83-93.

Patton, M. (2002). Qualitative research and evaluation methods. Thousand Oaks: Sage.

Pratolo, B. W. (2015). Exploring Indonesian learners' beliefs about language learning strategies through reflection. Doctoral Thesis: Monash University.

Rubin, J. (1975). What the good learner can teach us. TESOL Quarterly, 9(1), 41-50.

Taras, M. (2005). Assessment-summative and formative-some theoretical reflections. British Journal of Education Studies, 53(4), 466-478.

Yin, R. (1994). Case study research: design and methods. Beverly Hills: Sage Publishing. 